\title{
Gente do samba: malandragem e identidade nacional no final da Primeira República
}

\author{
Tiago de Melo Gomes
}

\section{Revisando o Mito}

Dentre os poucos temas da música popular que despertaram um interesse significativo da bibliografia acadêmica encontra-se a malandragem, tema que foi abordado por diversos trabalhos a partir de uma série de pontos comuns, resumidos a seguir ${ }^{1}$. Sua história começaria na década de 1880 , quando um imenso contingente de ex-escravos obteve sua liberdade. Traumatizados por anos de trabalho compulsório, tais indivíduos teriam, ao se verem livres, abdicado do trabalho regular, identificado à escravidão. Passando a viver entre os contingentes marginalizados de cidades como o Rio de Janeiro, esses indivíduos encontrariam seu meio de expressão no samba, ritmo de origem popular, nascendo nesse momento o samba malandro. Este estilo musical seria então perseguido na Era Vargas, devido a seu caráter potencialmente desestabilizador da ideologia trabalhista que então se buscava implantar. Para se contrapor ao samba malandro, a máquina ideológica do governo varguista teria produzido o samba exaltação, sempre apontando as grandezas do país e as vantagens de se trabalhar honestamente. Assim, através da censura e do aliciamento, a malandragem seria afastada do meio musical nos anos do Estado Novo.

É interessante sublinhar o fato de que tal tese, que busca explicar a presença da malandragem no samba, é na realidade um produto multidisciplinar, com trabalhos oriundos de vários campos desenvolvendo concepções semelhantes a respeito do assunto, ainda que com variações ${ }^{2}$. Cabe notar ainda que a aceitação dessa tese foi intensa, sendo freqüentemente citada em textos que tratam de música popular nos anos 1930 e mesmo 
em trabalhos mais gerais sobre o período. Contudo, à luz de pesquisas mais recentes, percebe-se que essa versão da história da malandragem possui pontos problemáticos. Pode-se observar que pressupõe uma fuga generalizada dos ex-escravos e seus descendentes em relação ao trabalho por várias décadas após 1888, o que é uma reprodução dos argumentos dos senhores de escravos em sua defesa da imigração européia por considerarem os escravos e libertos incapazes de servirem como trabalhadores assalariados (AZEVEDO, 1987). Além disso, supõe ainda uma imposição estatal do capitalismo na Era Vargas, reproduzindo desta vez o discurso produzido pelo regime do ditador (CHAUÍ, 1985).

Contudo, há uma outra questão, esta ligada diretamente ao campo musical: enquanto tal bibliografia constrói o samba malandro como um contraponto ao mundo burguês capitalista, a verdade é que há poucas composições que critiquem o trabalho e apresentem a malandragem como alternativa, mesmo antes do Estado Novo. Naturalmente há um número infindável de canções tratando de temas como infidelidade, boêmia, e as diversas formas de viver fora do mundo do trabalho assalariado. Mas, por certo, isto está longe de conferir qualquer tipo de significado especial a tais composições, sendo temas constantes da cultura ocidental ${ }^{3}$. Para demonstrar a especificidade de uma tradição malandra no interior do samba e que funcionaria como resistência à implantação do capitalismo, seria necessário reunir uma razoável quantidade de canções opondo o trabalho à malandragem, coletadas em lugares e épocas diversas, estudar sua evolução e relacioná-las com seus contextos específicos. Contudo, percorrendo as páginas dos trabalhos sobre o assunto (ou mesmo buscando antigas partituras, livros sobre música popular com outros enfoques ou outras fontes), nota-se que estas canções não se constituem em um grande número. Mais que isto: mesmo estas poucas cançôes podem ser nitidamente circunscritas no tempo e no espaço - são canções produzidas no Rio de Janeiro, na virada dos anos 1920 para a década de 1930 .

Dentre as composições que se referem especificamente à malandragem, tem-se "Ora Vejam Só”, de Sinhô, gravada pela primeira vez em 1927:

Ora vejam só/A mulher que eu arranjei/Ela me faz carinhos até demais/ Chorando, ela me pede/Meu benzinho/Deixa a malandragem se és capaz. 
A malandragem é um curso primário/Que a qualquer é bem necessário/é o arranco da prática da vida/que só a morte decide o contrário.

É possível notar aqui um explícito elogio à malandragem, definindoa em termos de necessidade de sobrevivência, e não como escolha pessoal. Não aparece aqui, portanto, uma crítica ao trabalho ou à sociedade burguesa. Em 1928, explorando o mesmo tema que já fazia sucesso, Alcebíades Barcelos (Bide), lançou "A Malandragem”:

A malandragem, eu vou deixar/Eu não quero saber da orgia/Mulher do meu bem querer/Esta vida não tem mais valia.

(...)/Arranjei uma mulher/Que me dá toda a vantagem/Vou virar almofadinha/Vou deixar a malandragem.

Vê-se neste samba que, no campo musical, a malandragem nasceu junto com a regeneração, de forma que esta não pode ser vista como uma criação da censura de Vargas (conforme afirmam PEDRO, 1980:82-104; MATOS, 1982:67). A canção afirma um explícito desejo de abandonar a malandragem, indicando que não se trata de um elogio ao ócio ou à vadiagem. Já em 1931 seria lançado “O Que Será de Mim?”, finalmente trazendo diversos elementos tradicionalmente relacionados ao samba malandro:

Se eu precisar algum dia/De ir pro batente/Não sei o que será/Pois vivo na malandragem /E vida melhor não há.

Minha malandragem é fina/Não desfazendo de ninguém/Deus é quem nos dá a sina/E o valor dá-se a quem tem.

O samba de Ismael Silva e Nilton Bastos é claramente uma exaltação orgulhosa da malandragem, vista como um dom e associada à elegância proporcionada pelo dinheiro obtido no jogo. A oposição da malandragem ao trabalho também surge logo nos primeiros versos, embora ainda não se trate especificamente de uma exaltação da malandragem que a tornaria superior ao trabalho regular, já que o status do trabalhador não é diminuído, ao menos explicitamente ("Não desfazendo de ninguém/Deus é quem nos dá a sina"), pelo orgulhoso narrador da canção. Tal fato se daria finalmente no exemplo mais característico do gênero: "Lenço no Pescoço", de Wilson Batista, lançado em 1932 na voz de Sílvio Caldas: 
Meu chapéu de lado, tamanco arrastando/Lenço no pescoço, navalha no bolso/ Eu passo gingando, provoco e desafio/Eu tenho orgulho de ser tão vadio.

Sei que eles falam deste meu proceder/Eu vejo quem trabalha andar no misere/ Eu fui vadio, porque tive inclinação/Eu me lembro era criança, tirava samba-canção.

Aqui estão apresentados explicitamente os elementos que têm fundamentado a bibliografia que associa a malandragem à resistência anticapitalista. O principal deles, a oposição entre a malandragem e o trabalho, com a explícita crítica ao segundo e exaltação à primeira, deixa claro por que tal canção seduziu os autores que desenvolveram tal associação. Contudo, parece extremamente arriscado propor qualquer tipo de generalização a partir de "Lenço no Pescoço", por se tratar de um caso singular, de autoria de um compositor que escreveu sobre muitos temas (incluindo a regeneração associada ao elogio do trabalho, no famoso "Bonde São Januário" ${ }^{4}$ ). Na verdade sequer há motivos concretos para crer que Wilson Batista compartilhasse qualquer das idéias difundidas pelo narrador de "Lenço no Pescoço"; é impossível, por exemplo, deixar de conjeturar que Batista (então um compositor novato, recém-chegado à Capital Federal com seus dezenove anos de idade) estivesse buscando inspiração em uma temática que estava em voga para obter seu primeiro sucesso. Essa hipótese é plausível na medida em que sua composição surge exatamente no auge da exaltação à malandragem no campo da música popular.

A vigência de tais composições no período é atestada não apenas por seus sucessos, mas pelas composições do período que não alcançaram a fama. Escrevendo em 1933, Orestes Barbosa (1978) cita diversos sambas do gênero, como "Salve a Malandragem", de Mano Edgar, compositor do bairro do Estácio, o que pode indicar a presença de entusiasmo popular pelo tema. Contudo, há o outro lado da questão: autores com experiências de vida inteiramente diversas que buscavam o sucesso com composiçôes exaltando a malandragem. Em 1930, por exemplo, o jovem estudante de Direito, Vinícius de Moraes, realizava uma de suas primeiras tentativas no campo da música popular, em parceria com os Irmãos Tapajós: 
Ai! eu vou me pirá/Não quero trabalhá/Malandro eu nasci/Sou malandro já se vê/Malandro hei de morrer/ (...)

Amo botequim/Uma mulata sambando/Deixa a gente sem coragem e por isso Viva e viva a malandragem (citado em CASTELLO, 1997:50).

Ao ler-se a letra composta pelo estudante de dezessete anos, percebese que tal profissão de fé na malandragem rivaliza com qualquer outra daquelas aqui apresentadas, mesmo na comparação com Ismael Silva ou Wilson Batista. Isto basta para demonstrar que, em seu auge, a exaltação da malandragem não era privilégio ou monopólio de nenhum segmento social. Se por um lado compositores afro-brasileiros pobres se fizeram presentes com canções do gênero, autores de origem inteiramente diversa fizeram incursóes nesse campo. Após esse momento de intensa voga, o samba malandro perderia parte de sua força, principalmente as modalidades que pudessem ser confundidas com críticas ao trabalho enquanto instituição, tal como "Lenço no Pescoço", inclusive devido ao advento da Era Vargas. Mas, se o Estado Novo contribuiria para bloquear um tipo de samba malandro, sua concepção ideológica que caracterizaria o país pela singularidade acabaria por ser aberto à aceitação de sambas de estilo malandro caracterizados pela astúcia, do tipo explorado por Moreira da Silva. O tema da regeneração, por outro lado, por se adequar a certo tipo de composição amorosa mais brejeira, acabaria se consolidando e vencendo décadas ainda com sucesso. Essas vertentes que permaneceram vivas nas décadas seguintes acabariam por garantir definitivamente a sobrevivência da malandragem no samba, mantendo-o vivo sem rígidas distinções de classe social e mediado por experiências de todos os matizes.

Para leitores familiarizados com a bibliografia acadêmica produzida sobre o assunto, a idéia de que o samba malandro tenha sido, ao menos em parte, uma estratégia de alguns de seus compositores pode soar estranha. Contudo, a trajetória desse gênero musical encontra um grande número de paralelos no mundo musical daqueles anos. Embora o mercado fonográfico do período ainda seja diminuto e as rádios pouco ou nada pagassem aos autores de músicas reproduzidas, existia a possibilidade de se obter algum dinheiro investindo nesses meios, em especial no que se refere à música carnavalesca (LAGO, 1976:139). Essa situação criava um período 
específico onde, devido ao menor tamanho do mercado do disco no restante do ano, se dava de modo acentuado o choque entre os compositores em busca do sucesso. E como um grande sucesso carnavalesco poderia impulsionar a venda dos discos de determinada canção, os autores tinham necessariamente de buscar um grande sucesso naqueles três dias.

Com isto, criaram-se algumas estratégias em busca do sucesso que atraíram compositores durante muitos anos na busca pela glória. Um exemplo típico é o das composiçôes com nomes de mulher, que por cerca de vinte anos se fizeram presentes em praticamente todos os carnavais, incluindo sucessos do porte de "Aurora" (Roberto Roberti - Mário Lago, 1940) e "Ai Que Saudades da Amélia” (Ataulfo Alves - Mário Lago, 1941), entre outras. O exemplo sugere que, no período aqui estudado, a cultura de massas havia chegado a um estágio em que cada vez valia mais a pena lutar pelo sucesso em busca de recompensa financeira. Como resultado, as disputas se intensificam, e muitas vezes os gêneros musicais passam a observar ciclos menores de duração, resultando muitas vezes em simples repetição de um tema em uma música posterior. Ao estudar a composição carnavalesca do período, um autor chegaria a conclusão semelhante:

A inspiração dos compositores carnavalescos é bastante limitada. Principalmente quanto à temática. Quando uma composição faz sucesso, no ano seguinte são inúmeras as que lhe vão nas águas, aproveitando os mesmos motivos, a mesma frase de efeito, as mesmas onomatopéias e até o mesmo título. Daí os ciclos carnavalescos. Da pigmentação da pele. Do cabelo. Dos nomes de mulher. Da malandragem. Da China. Do Tirol. Dos bairros cariocas. De Alá. Das lágrimas. Do choro de criança, etc., etc. (ALENCAR, 1985:303).

Mais importante que o evidente juízo de valor, baseado na valorização da idéia de originalidade, é o fato de que Alencar ajuda a formar um quadro onde, devido a condiçóes específicas da cultura de massas, alguns gêneros - o samba malandro incluído - poderiam ascender ao sucesso e perder prestígio em seguida, não tendo este fato necessariamente ligações estreitas com sentimentos populares em relação ao tema das canções.

Relacionar a malandragem como mais um gênero musical disponível no disputado mundo da canção popular de seu tempo pode, à primeira vista, parecer niilista, esvaziando não apenas o samba malandro, como to- 
das as composições do período de qualquer tipo de significado. Contudo, até o presente momento pretendeu-se tão somente estabelecer um diálogo crítico com o argumento de que o samba malandro seria uma tradição imemorial reprimida pelo Estado Novo por veicular uma ideologia perigosa. Os argumentos que se seguem visam apontar tal gênero como um desdobramento dos debates a respeito da identidade nacional que se desenrolavam nos palcos do teatro de revista, e seu papel em toda a discussão do tema, que se desenrolava na sociedade como um todo.

\section{Cruzando Fronteiras}

Pode-se abrir esta seção respondendo a uma pergunta: se o samba malandro não era uma tradição longínqua, qual teria sido efetivamente sua origem? Por certo ela deve ser procurada em outro lugar muito específico: o teatro de revista. Tal gênero teatral, bastante popular na primeira metade do século XX, era um espaço onde se dava um franco diálogo com o mundo da música popular: não faltam provas de que nos palcos musicados da cidade do Rio de Janeiro canções eram lançadas e/ou popularizadas e que artistas moviam-se livremente entre os dois meios (ALENCAR, 1981; GOMES, 1998; PAIVA, 1991; VENEZIANO, 1996). Afinal, com a popularização do teatro de revista e a ausência de meios de divulgação de peso, como um mercado discográfico e radiofônico forte, a colocação de músicas em peças era uma chance importante para um compositor ou cantor popularizar seus produtos. Por outro lado, nada melhor para um revistógrafo que aproveitar canções de sucesso para popularizar suas peças, principalmente se estas canções fossem interpretadas por estrelas como Margarida Max ou Araci Cortes.

Por outro lado, vários revistógrafos chegaram inclusive a ser co-autores de sucessos populares, já que as partituras sempre possuíam uma parte composta especialmente para determinada peça, cabendo muitas vezes aos autores da mesma a tarefa de colocar a letra na música. Assim, Luís Peixoto tornou-se um nome destacado na música popular, pois, embora fosse fundamentalmente um homem do teatro de revista, assinou letras de muitas músicas que chegaram ao sucesso. Outros autores de peças chegaram a grandes sucessos: Ari Pavão foi autor da letra de "Chuá Chuá", música 
composta pelo maestro Sá Pereira para a revista Comidas, Meu Santo!, de 1925 , e que se tornou um dos grandes sucessos da década, assim como "Zizinha", música composta por Freitinhas para a revista Se a Moda Pega e que após receber letra de Carlos Bittencourt e Cardoso de Menezes tornou-se um dos grandes sucessos de 1926. Assim, torna-se claro que não se pode estudar o teatro de revista dos anos 1920 perdendo-se de vista a música popular, e vice-versa.

Toda essa ligação entre o teatro de revista e a música popular apóia a idéia de que o samba malandro tenha suas origens nos palcos da revista carioca, mesmo porque tanto o malandro quanto os demais tipos de grande sucesso no teatro de revista decolariam, a partir dos anos 1920, para carreiras duradouras também no cinema e na música popular. Malandros, mulatas, caipiras e portugueses se fazem presentes, por exemplo, nas chanchadas, no humor radiofônico, televisivo e teatral, com muita freqüência, principalmente a partir dos anos 1920 e até os dias de hojes.

Em relação à malandragem, é possível identificar uma notável simetria entre sua popularidade nos palcos e seu surgimento na música popular. As primeiras músicas de sucesso calcadas nessa temática apareceram nos últimos anos da década de 1920. Já nos palcos, embora existente há muitos anos (VENEZIANO, 1991:122-124), a malandragem ocupou um lugar mais central a partir do mesmo período, uma vez que nos anos 1920 uma noção "malandra" do Brasil assumiu grande importância no teatro de revista carioca (GOMES, 1998). Neste contexto a malandragem passou a ser vista como representante de um país que tinha orgulho do caráter singular de suas classes populares. Pode-se lembrar a peça Seu Julinho Vem, grande sucesso do ano de 1929, escrita por Freire Jr. Após um primeiro ato no qual um habitante de morro de nome Vagabundo apresenta-se como defensor das tradições populares, o segundo ato mostra o mesmo personagem sendo levado ao Centro dos Malandros. Lá chegando, Vagabundo se surpreende ao perceber que a malandragem está difundida por todas as classes, principalmente nas mais altas. O diretor do Centro canta a já citada "A Malandragem", ao que Vagabundo responde cantando "A Vadiagem", de Francisco Alves (canções que chegaram a obter algum destaque após serem lançadas nesta peça). Aqui Freire Jr. mostra um país dominado em todos os seus extratos sociais pela malandragem, que parece simbolizar toda a nação. 
Além disso, a presença destes dois sambas corrobora a ligação entre a malandragem do samba e a dos palcos, tendo a revista possibilitado a existência de algo similar na canção popular, que por seu lado fortaleceu o tipo dos palcos. Deve-se notar, a propósito, o estilo da maioria dos sambas malandros, sempre adequados para utilização na revista, inclusive sendo a maior parte em primeira pessoa, tornando-os ideais para o aproveitamento em diálogos.

Com isso, é possível observar que parte da origem do samba malandro se deve ao teatro de revista, espaço onde o personagem estava chegando a seu ápice justamente no momento em que surgem os primeiros sambas malandros. Na verdade, o citado "Ora Vejam Só" teve longa vida na revista: apresentado na revista Prestes a Chegar, de 1926, nomeou uma outra peça dois anos depois, escrita por Jota Martins no mesmo ano em que conheceu sua segunda gravação. Nota-se então que a malandragem teve grande popularidade no teatro de revista, meio caracterizado por uma constante e imensa troca cultural, com a contribuição de pessoas de diversas classes e experiências sociais. Na revista, a malandragem foi símbolo de uma perceptível redefinição das discussões sobre a questão da identidade nacional, característica dos anos 1920, assim como de um reordenamento das convençôes da própria revista, frente a um público que se diversificava progressivamente; com isto, acabou chegando ao samba, onde repetiu seu êxito, o que acabou fortalecendo sua presença nos palcos. Esta constante mão dupla entre o samba e a revista é certamente uma parte substantiva na explicação do surgimento do samba malandro.

Criado e desenvolvido a partir do teatro de revista em um contexto favorável tanto no plano da cultura de massas quanto de sua institucionalização como parte integrante do caráter nacional, o samba malandro se consolida definitivamente ao firmar-se como gênero musical na virada da década de 1930. Neste caso, a noção de gênero não apenas serve como elemento explicativo da consolidação do samba malandro, mas ajuda a dar sentido a toda a produção musical no período. Como paralelo ao samba malandro, vale lembrar neste sentido o gênero conhecido como samba exaltação.

Desde o século XIX as revistas traziam apoteoses finais de cunho exaltativo. Os temas exaltados eram variados, podendo ser algum fato tea- 
tral ou político considerado relevante. Mesmo com as mudanças atravessadas na estrutura do teatro de revista, manteve-se ao longo dos tempos a tradição de encerrar as peças com uma apoteose onde se exalta algo de escolha do autor ou do ensaiador. Nos anos 1920, com o progressivo aumento das exibiçôes de orgulho nacionalista, as apoteoses exaltativas à nacionalidade, sejam elas ligadas ao "povo brasileiro" ou às "riquezas naturais", tornaram-se cada vez mais recorrentes. No final da década o gênero já estava consolidado na revista, vindo a dar seu fruto mais famoso no final dos anos 1930, com “Aquarela do Brasil”, música não por acaso apresentada inicialmente no espetáculo Joujoux e Balangandãs, de Henrique Pongetti. Mas já nos anos 1920 o gênero se faria presente:

A minha terra/Tesouros mil no seio encerra/É linda e pura/Como no mundo não existe igual!/Tanta fartura/A natureza ao sol a reluzir/Tem ventura/ Tem condão de seduzir (bis)

A minha terra/Tesouros mil no seio encerra/mulher amada/Abençoada/Por seu povo

Diante de ti Brasil/Meu céu azul de anil/Não há no mundo/Alguém/Que não te queira bem (bis)

A natureza/Jogou em ti/De luz tanta beleza/Que ninguém pode te admirar/ Sem se ajoelhar

A natureza/Jogou em ti/Sem ver/Tanta beleza/Que ninguém/Pode esquecer ${ }^{6}$.

Não é difícil perceber nesta composição de 1929 os elementos básicos dos sambas exaltação apresentados por muitos como sendo de inspiração estadonovista, assim como dos sambas-enredo característicos das décadas de 40 e 50, igualmente apresentados como frutos da intervenção varguista. Contudo, se o ditador e sua máquina de propaganda por certo viam com bons olhos estes produtos, não se pode creditar ao Estado Novo tamanho mérito. Além de peças do teatro de revista trazerem desde a Primeira República canções com a mesma temática dos sambas exaltação, pode-se lembrar que as próprias escolas de samba decidiram por conta própria ter necessariamente enredos nacionais (AUGRAS, 1993), e o mesmo já havia ocorrido com diversos ranchos ainda nos anos 1920 (CUNHA, 2001:256-261). Nota-se então que tais temáticas "nacionais" estavam em alta no campo da música popular antes de a máquina varguista entrar em 
ação. Não foi por acaso certamente que outras peças apresentariam composiçôes do gênero. A música, cuja letra é transcrita em seguida, foi escrita para a revista $\hat{E} d a$ Pontinha, de 1927:

Grandes Brasileiros/Cada um é um empreendedor/Elevando o Brasil/Às glórias e ao esplendor

Ó doce mãe/Alma grande e pioneira/Espalhaste no universo/O valor da mulher brasileira

Brasil Querido/Grandes são os filhos teus/Berço de Santos Dumont/Foste abençoado por Deus.

Neste caso, o objeto exaltado é a nação e seu povo, enquanto que na música anterior a exaltação se dá mais diretamente em relação às riquezas naturais. Assumindo qualquer uma destas formas, os gêneros exaltativos atravessaram a década de 1920, tornando-se estilos de composição popular propriamente ditos. Neste sentido, guardam semelhanças com o samba malandro, ambos podendo ser vistos como frutos do teatro musicado que ganharam vida própria no mundo da música popular.

\section{0 Mistério do Samba}

Conforme demonstrado anteriormente, a malandragem foi vista por muitos como um estilo de composição altamente difundido ao longo da Primeira República, sendo extirpado devido à ação do governo Vargas devido a seu potencial subversivo. Este ponto de vista pressupóe, naturalmente, que o samba fosse o gênero musical dominante no período, e que o samba malandro fosse uma de suas vertentes mais importantes. De fato, é possível notar que as referências à música popular na década de 1920, principalmente nos trabalhos que buscam realizar sínteses de história da música popular brasileira, se dêem basicamente em função do samba e/ou do maxixe, ora sob o aspecto da perseguição, ora sob o da resistência (CALDAS, 1985; KRAUSCHE, 1983). Nota-se, neste caso, a aceitação plena de uma construção: o samba como resultado da "alma popular" dominando o cenário musical a partir do período correspondido entre os anos 1910 e 1920. Nesta versão consolidada, o samba surge como o produto de uma tradiçãa popular que resistiu à perseguição e ao preconceito até o triunfo. 
Recentemente, Vianna (1995) analisou a ascensão do samba dentro de uma outra perspectiva: a de que o samba tivesse sido valorizado em um contexto de produção de símbolos nacionais. Embora neste ponto sua análise pareça convincente, a própria construção de seu programa tende a deixar de fora algumas questôes centrais. Era enorme a variedade de ritmos circulantes no Rio de Janeiro dos anos 1920. Músicas norte-americanas já ocupavam lugar central, e ritmos como foxtrot, shimmy e charleston se faziam presentes com força considerável. Ritmos de outros países da América Latina, músicas interioranas de todos os matizes, polcas, choros, músicas de influência africana, maxixes, entre outros ritmos, disputavam a preferência musical do público. Assim, em relação à análise de Vianna, é possível concordar que o sucesso do samba tenha sido fruto da procura de um "ritmo nacional por excelência", mas é igualmente possível questionar o porquê de o samba ter sido o gênero escolhido. Pode-se lembrar que o maxixe fazia sucesso há muitas décadas, e os gêneros então chamados "sertanejos" seduziam o público pelo menos desde os anos 1910, e muitos dos sucessos dos anos 1920 remetem a estes estilos ${ }^{7}$.

Ao não indagar por que o samba teve a primazia sobre estes outros gêneros de música popular ao ser transformado em "música nacional", Vianna parece crer que, em uma visão "mestiça”" na nacionalidade, apenas o samba poderia ser visto como o ritmo nacional por excelência, quando, na verdade, o maxixe e os gêneros sertanejos pareciam estar mais próximos da consagração, tendo em vista seu sucesso duradouro e seu prestígio relativamente consolidado quando a década de 1920 caminhava para seu final. Basta que se lembre a revista-burleta Não Quero Saber da Orgia, onde um malandro de morro transmite o sentimento nacional tocando modinhas em sua viola, para se perceber claramente que se tratava de um momento em que ainda não estava claro para os contemporâneos qual gênero seria o candidato mais sério ao status de "ritmo nacional por excelência". O samba ainda era um ritmo novo no final dos anos 1920, enquanto que o maxixe e a música sertaneja já estavam mais consolidados na preferência popular e dos intelectuais empenhados em criar uma idéia nova de nacionalidade. O próprio termo "samba" ainda não estava definido claramente, englobando naquele momento uma razoável diversidade de gêneros musicais ${ }^{8}$. Assim, questôes ideológicas podem explicar a busca de um "ritmo nacional", e 
principalmente o fato de se privilegiar a música popular como fonte desta busca. Mas não explicam por si só o porquê de esta primazia ter sido dada ao samba, e não a outro gênero qualquer dentre os que naquele momento eram vistos como "populares".

Acredito que uma boa pista para a resposta está no malandro Vagabundo, da citada Seu Julinho Vem. Na construção do personagem aparecia uma idéia que se tornava dia a dia mais generalizada: a de que os morros da cidade do Rio de Janeiro seriam imensas reservas da mais autêntica cultura nacional. Nas páginas que se seguem argumentarei que, ao agregar imagens poderosamente simbólicas de autenticidade cultural popular (samba, malandragem, morro, artistas afro-brasileiros), o samba malandro tornouse o agente que definiria o samba como "ritmo nacional por excelência", o que imortalizaria seus músicos e perpetuaria suas criações.

\section{Gente do Samba}

Após as experiências pioneiras de Thomas Edison no estado de New Jersey na década de 1870 , as chamadas machinas fallantes começaram a ser produzidas em escala comercial já no século XIX. Até os últimos anos da década de 1920 vigorava a gravação mecânica, tornando estas gravaçóes pouco agradáveis para os ouvidos atuais, uma vez que as vozes dos cantores da época apareciam encobertas por instrumentos pouco distinguíveis entre si e bastante descoloridas, tornando improvável qualquer sutileza vocal. A partir de 1927, data da chegada da gravação elétrica ao Brasil, as gravaçôes têm um salto qualitativo, possibilitando que a intensa circulação de idéias do período ganhe mais uma arena.

Paralelamente a esta mudança motivada por questões técnicas, fez-se notar o advento de uma nova geração de compositores que viria a redefinir inteiramente o conceito musical do termo "samba". Enquanto nos anos 1920 compositores como Sinhô rotulavam como "samba" um gênero musical hoje classificado como "maxixe", os novos compositores seriam responsáveis pelo desenvolvimento de um ritmo mais balançado e gingado que obteria ampla aceitação, passando a figurar após este período como "o verdadeiro samba". As origens musicais e as influências sofridas por estes novos compositores jamais ficaram suficientemente explicadas. Ismael 
Silva, compositor mais destacado do bairro do Estácio, onde teria surgido o novo ritmo, atribuía seu surgimento à necessidade de um ritmo mais apropriado para os desfiles carnavalescos, como os das escolas de samba, conforme declarou a Sérgio Cabral:

Quando comecei, o samba não dava para os agrupamentos carnavalescos andarem nas ruas, conforme a gente vê hoje em dia [1974]. O estilo não dava para andar. Comecei a notar que havia esta coisa. O samba era assim: $\tan \tan \tan \tan \operatorname{tantan.~Não~dava.~Como~é~que~um~bloco~ia~andar~na~rua~as-~}$ sim? Aí, a gente começou a fazer um samba assim:

bum bum paticumbumprugurundum...

Nem tudo que se diz se faz/Eu digo e serei capaz/De não resistir/Nem é bom falar/Se a orgia se acabar. (CABRAL, 1996:242)

O novo estilo de compor sambas viria a se casar muito bem com as possibilidades oferecidas pelo microfone elétrico. Por outro lado, o momento histórico em muito contribuiu para a ascensão do samba, em conjunto com a da malandragem. $\mathrm{O}$ samba passou ao primeiro plano como ritmo nacional em um momento em que a malandragem era vista de forma mais positiva. $\mathrm{O}$ samba malandro surge precisamente neste momento, e nem um nem outro jamais se livrariam desta ligação. A construção da idéia de que o vigor da nação brasileira estava na chamada "alma popular" (amplamente discutido no período, e não apenas pelos modernistas, ver SEVCENKO, 1992) levou a um progressivo interesse pela vida dos subúrbios e principalmente dos morros, não apenas no teatro de revista, mas também em outros meios. Entre outros símbolos deste que era continuamente construído como um mundo à parte, o samba e a malandragem ocupavam um lugar especial. A malandragem seria reconhecida como fenômeno típico do pitoresco ambiente, enquanto o samba viria a ser visto como a sua mais pura expressão cultural. E pode-se notar que o processo de valorização dos morros como espaços onde a alma popular se manifestaria livremente surge com mais força exatamente no período em que o samba malandro chega ao sucesso: a virada da década de 1920 para os anos 30. Afinal, ainda em 1926 era freqüente encontrar nos jornais cariocas notícias como a que se segue: 
As autoridades do $18^{\circ}$ distrito têm dado cerradas batidas no morro da Mangueira, com o fito louvável de sanear aquela perigosa localidade, que é um valhacouto de desordeiros.

É tão asqueroso em tudo, tão baldos os princípios de higiene ali, que urgente seria uma comunhão de esforços da Prefeitura, da Saúde Pública e da Polícia para vencer, de todos os modos, o morro da Mangueira.

Ali não são valentes apenas os homens; as mulheres também são decididas, brigam com armas em punho, como ainda ontem sucedeu no momento em que a caravana policial passava, o que não impediu que a agressora fugisse ${ }^{9}$.

Se tal passagem não deixa espaço para ambigüidades, apresentado aos leitores um perigoso inimigo a ser derrotado, em breve seria possível encontrar novos olhares da imprensa em direção a localidades como a hoje celebrada Mangueira. Nos primeiros meses de 1928, quando "Ora Vejam Só” já conhecia sua segunda gravação e diversas peças tendo a malandragem como tema central chegavam à praça Tiradentes, os leitores do periódico $A$ Noite poderiam ler uma reportagem sobre o famoso Morro do Pinto, que apresentava uma tentativa de revisão em relação à postura recorrente de ver nos morros da cidade apenas "valhacoutos de desordeiros".

Quem ouve falar em morro do Pinto tem a impressão de que se trata de uma zona do barulho, de constantes conflitos, onde cada habitante tem cara de valente.

É que o morro do Pinto na verdade já teve os seus valentes, levados à fama pelo noticiário dos jornais, como "Antonico do Morro", que andava com o fogo no bolso, o punhal na cava do colete e a navalha empalmada, sempre que estava embriagado. $O$ terrível malandro era, entretanto, um ébrio perene, e tinha um pendor característico para as grandes façanhas.

(...) O morro do Pinto está modernizado. Não tem mais valentes. Mora ali uma gente boa, honesta e pacata: operários da Central do Brasil, operários de fábricas, soldados da Polícia Militar, contínuos e serventes de repartiçôes públicas.

Muita gente há, contudo, que ainda crê que no morro do Pinto só há malandros, valentes e mendigos. 
(...) De outra coisa se queixam os moradores do morro do Pinto: ali não há polícia (...) E para que polícia? diria o visitante. Não há gente mais honesta e mais pacata que o morador do morro do Pinto.

Ali a criação anda solta na rua e ninguém se atreve a furtar sequer uma galinha. (...) No morro do Pinto só mora gente honesta, hoje em dia. Haja visto que ali nem há mais polícia.

Já passou o tempo em que ali era zona de mendigos, de malandros, de ladrões - o tempo, enfim, em que havia de fato, necessidade de polícia e polícia valente. Raramente agora ocorre ali um fato que mereça registro policial ${ }^{10}$.

O texto parece retratar um momento de transição: para o repórter, o morro do Pinto já poderia ser visto como um espaço quase paradisíaco, mas a construção do texto mostra que havia a expectativa de que tal perspectiva não fosse compartilhada com os leitores. Daí o fato de a reportagem adotar um tom que claramente visa convencer os leitores que imaginam ser os morros "valhacoutos de desordeiros" de que a situação modificou-se, e tais espaços agora podem ser freqüentados sem temor pelo habitante da cidade, sendo habitados apenas por "gente honesta". Vale notar que o repórter não parece se questionar sobre a premissa anterior, acreditando que de fato o morro do Pinto havia sido de fato uma "zona de mendigos, de malandros, de ladrões"; para ele, o morro do Pinto havia mudado, e não sua própria percepção do famoso morro. $\mathrm{O}$ mesmo tom é adotado, por sinal, na carta enviada ao jornal por Oscar Machado da Silva, presidente do Centro Político de Melhoramentos do Morro do Pinto, agradecendo a matéria anterior: "O morro do Pinto não é mais, como bem dissestes, o de outrora; atualmente moram nesse outeiro carioca, cerca de oito mil almas honestas e trabalhadoras, de costumes morigerados"11.

Outro elemento que pode ser retirado do texto é o fato de "malandro" ser uma palavra usada com conotação explicitamente negativa, e o autor respira aliviado por o morro do Pinto não ser mais uma "zona de mendigos, de malandros, de ladrões". Tal passagem mostra que o termo "malandro", a despeito de tornar-se bastante expressivo na definição da identidade nacional, jamais perderia sua associação com o mundo do crime, tornando-se um termo polissêmico por excelência. Mas o uso de tal acepção do termo mostra ainda que a visão de tal repórter sobre o morro do Pinto 
se situava em um momento de transição, em que este repertório de imagens associando morros a samba, malandragem e pureza ainda não estava plenamente consolidado. O que não surpreende, pois ainda estava-se em 1928, portanto um momento inicial da popularização deste repertório simbólico. Mas, pouco tempo depois a situação seria bastante diferente, a se julgar por uma matéria denominada "Gente do Samba", de autoria de Carlos Cavalcanti (A Crítica, 22-3-30). A própria introdução da matéria mostra suficientemente o quanto está impregnada desse repertório de imagens:

Gente do samba! Gente das ruas, dos becos, das vielas, dos botequins, dos morros, dos bailes, das noites e do Amor e do Sonho da Cidade. Gente que mal escreve, pior lê, mas que nos dá um tesouro de coisas que se escrevam e se digam sobre os mais belos e naturais motivos da alma humana.

Outro dia, nós fomos à casa do malandro, gente do samba, e viemos tão encantados que nos apressamos a voltar com o leitor, trazendo-o não como uma visita de cerimônia, porque, como os versos do seu morador, ela é de todo mundo, entra-se sem pedir licença e não mais se tem vontade de sair.

Aqui o termo "malandro" aparece em um contexto inteiramente diverso, servindo como sinônimo para "gente do samba". Já se percebe aqui que samba e malandro são os referenciais básicos de um mundo à parte denominado "morro", onde a vida é regida por um conjunto de valores inteiramente diversos da sociedade burguesa, um mundo de sonho, prazer e constante diversão. Os parágrafos seguintes do texto afirmam que o público pouco sabe acerca dos compositores dos sambas mais famosos da cidade, o que o leva a afirmar:

Ora, o leitor, após o jantar, quando se mete fagueiro no seu pijama e põe o disco que comprou na cidade, ouve sambas, é certo, mas roubados na autoria aos seus criadores. Estes, enquanto os pretensos figuram nas letras douradas, ficam no maciço escuro, que é onde está a alma luminosa da melodia gravada.

Assim eles, quase desconhecidos, vivem anônimos dentro de suas belezas, e raras vezes a cidade vai bater-lhe a porta do barracão no Estácio, no morro do Salgueiro, no da Mangueira, em Osvaldo Cruz, povoados de menestréis para apresentá-los em público. 


\section{A Pátria do Samba}

O bairro do Estácio encravado entre o morro de São Carlos e as ruas, que parecem não ter fim, do baixo meretrício. De um lado, o crime, de outro, a carne, e no meio, o malandro sonhando. É entre estes dois mundos, imensos e lúgubres, negregados de misérias, que ele, visionário romântico, ama idealmente, às vezes, e vive no jardim maravilhoso dos seus sonhos.

$\mathrm{E}$ as noites, aquelas noites lactescentes e liriais, nas quais se intumescem as paixões dos poetas incompreendidos sobe ao ar, como um perfume, como indefinida aspiração, uma toada longínqua, cheia de langores, triste como uma saudade que se vai perder, desmancham-se no murmúrio de febres e fatalismo que se alevanta do bairro das mulheres. Um coro, que se sobreleva, acompanha o cantador, que talvez seja um Nilton ou Ismael pondo à mostra os conflitos do seu coração amoroso.

Os parágrafos citados são extremamente densos, expondo de forma límpida o imaginário que permitiu a ascensão do samba e do malandro ao status de símbolos nacionais. No primeiro parágrafo é exposta a idéia de que os sambistas são artistas que vivem num mundo à parte provendo a cidade de algumas de suas maiores pérolas, e que este mundo é inteiramente desconhecido dos leitores. $\mathrm{O}$ malandro aparece como alguém que conhece o mundo do crime e a prostituição, mas não está ligado a nenhum dos dois. Seu mundo é o do sonho, e tal posicionamento é explicado de modo a torná-lo virtualmente um poeta romântico sonhando com suas musas.

Após mais alguns parágrafos enaltecendo o bairro do Estácio como a "pátria do samba”, Cavalcanti abre uma nova seção em sua matéria.

\section{Como Nasce Um Samba}

O samba só pode nascer como sentimento do próprio malandro - foi o que nos disse com certa gravidade Nilton Bastos, o mais fluente e borbulhante "causeur" do grupo. Desata a língua, este Nilton, e palestra como se cantasse.

Aqui se nota que os próprios sambistas já haviam percebido que tipo de discurso lhes abriria mais portas. Nilton Bastos (que faleceria em 1931, atacado de tuberculose) é normalmente descrito por seus antigos compa- 
nheiros como um pacato funcionário público, mas nesta entrevista ao jornal carioca não perdeu a oportunidade de apresentar-se como um defensor da idéia de que o samba autêntico só poderia ser criado pelo malandro. Assim, o morador de um bairro de classe média (Vila Isabel) assume o discurso de defensor da autenticidade do samba produzido nos morros e endossa o discurso de que os malandros seriam compositores que expressariam seus mais convictos sentimentos em cada uma de suas canções. A fala de Bastos sugere não apenas que tal visão sobre sambistas e malandros já era bastante difundida, mas também que os próprios indivíduos enquadrados naqueles termos já haviam percebido inteiramente as vantagens disto, o que indica que samba e malandragem já possuíam uma aura de autenticidade em 1930, lançando a hipótese de que tal imaginário surgiu e generalizou-se com grande velocidade.

A parte seguinte da reportagem discute o significado do termo "malandro", classificando de "requinte inqualificável de má fé" o fato de a polícia ver na palavra um sinônimo de ladrão ou vagabundo, visão que segundo o autor teria sido aceita por muitos. Para o autor, malandros seriam "os do samba, líricos saborosamente primitivos e naturais, honestos e quase sempre pacatos". O autor abre então espaço para que seus entrevistados definam como vêem o termo:

Muitas das vezes eles vão falando, exuberantemente, numa espontaneidade oratória infatigável e tal a fluência de palavras que se desdizem, se contradizem, se repetem, numa infantilidade de idéias que perdoamos sorrindo.

Canuto, o canário de Vila Isabel, inseparável contudo dos seus companheiros de Estácio, onde sua figura avantajada de caboclo hercúleo é popular e simpática, não se envergonha de ser malandro, visto que define a sua posição com muita ufania e orgulho...

- Aquele que não trabalha é vagabundo, diz com sua voz de tenor. Malandros somos nós, que trabalha. Mas nas horas vagas, faz as suas "atrapalhações".

Gastão, quase um tímido, silencioso de poucas palavras e muitos versos, escutou a definição do companheiro. Achou que ele tinha razão às carradas e comentou: 
- É, julgo também que o malandro tem vantagem. Não pensar muito na vida para não se amofinar.

Logo após, Bide “intervém e afirma que não é vagabundo, mas gosta da vagabundagem”. Finalmente, a visão de Nilton Bastos, que "dogmático, peremptório, de dedo em riste, exclama":

- Malandro? Malandro é uma palavra muito fina. $\mathrm{O}$ malandro vive de inspiração, tem responsabilidades...

E, fazendo uma pausa hesitante, conclui:

- ... mas freqüenta sambas e bailes...

E, virando-se para os circunstantes:

- Estou errado?

Esta passagem do artigo publicado em $A$ Crítica concentra alguns elementos cruciais na valorização de sambistas e malandros. Em primeiro lugar não se pode deixar de sublinhar a condescendência de Cavalcanti em relação aos entrevistados, colocada de modo explícito no parágrafo anterior às declarações dos sambistas. Tal abordagem é perceptível em diversos discursos que se pretendem elogiosos a sambistas e malandros, incluindo trabalhos acadêmicos que mantêm a mesma idéia expressa por Carlos Cavalcanti na matéria acima, quando afirmam que "as letras de samba por muito tempo constituíram o principal, senão o único, documento verbal que as classes populares do Rio de Janeiro produziam autônoma e espontaneamente" (MATOS, 1982:22).

Mas a passagem citada acima é preciosa por permitir aos próprios sambistas definirem-se. Naturalmente tais afirmaçōes são fontes históricas que merecem ser tratadas como qualquer outra, principalmente devendo-se levar em conta as mediações através das quais chegaram até nós. Mas, de qualquer forma, trata-se de um documento raro: sambistas do período da Primeira República falando de si próprios ainda na juventude. E é importante notar que todos eles eram capazes de perceber com perfeição o que estava em jogo, colocando-se como malandros, e definindo este termo sempre como um estilo de vida fora da sociedade estabelecida, mas nunca sugerin- 
do um confronto ou oposição entre o mundo do samba e o mundo da ordem burguesa. O salgueirense Canuto notava que os malandros trabalhavam como qualquer outro indivíduo, deixando as "atrapalhações" para as horas vagas, visão semelhante à expressa por Bide. O sambista que o autor do artigo chama de Gastão define o malandro como alguém que leva a vida despreocupadamente, enquanto Nilton Bastos coloca em relevo o fato de o malandro ter "responsabilidades", mas viver de inspiração e freqüentar sambas e bailes. Ou seja, o malandro é visto por estes compositores (que não deixavam de estar se autodefinindo, já que em vários momentos falaram do malandro na primeira pessoa do plural) como alguém que vive uma fora das amarras sociais da vida burguesa, mas não oferece perigo a ninguém. Uma visão que, ainda que menos idílica que a do redator da matéria, guarda certo grau de idealização e obteve sucesso, já que se tornou padrão pelas décadas seguintes, sendo sacramentada pela bibliografia acadêmica sobre a malandragem.

$\mathrm{O}$ texto encerra-se com o autor afirmando que

A cidade conhece a gente que não é do samba, os Mário Reis, os Francisco Alves, os Pixinguinha, os Sinhô, "sambestas" que não vivem de inspiração e sim de, como forasteiros, penetrarem o Estácio, ouvirem-lhe os menestréis, atocaiá-los nas aperturas financeiras e despojá-los, a troco de ninharias, dos seus tesouros.

Tal passagem não deixa de surpreender ao apontar Pixinguinha como comprador de composições. Para o autor, esta situação levaria o samba, deformado pela apropriação, aos ambientes requintados da cidade, enriquecendo os falsos autores, ao passo que

Enquanto vivem assim estes, aqueles, os verdadeiramente do samba perambulam, desabrochando em toda parte os seus coraçōes, pelo Estácio, por Osvaldo Cruz, Vila Isabel, morro da Mangueira, do Salgueiro, pelos bailes, fandangos, noitadas e botequins. Cantando, sonhando, celebrando amores e aventuras, muito felizes da vida, dormindo e achando que é um presente do céu aparecerem aqueles cavalheiros paramentados de capitalistas a comprar-lhes as canções.

$\mathrm{O}$ autor encerra o texto reafirmando a idéia de que a cidade desconhece os verdadeiros autores de suas músicas mais conhecidas, bem como 
seu particular modo de vida. O autor, ao falar de morros, malandros e sambistas, por vezes utiliza recursos que se aproximam das narrativas de viagem, praticamente adotando a postura de trazer aos habitantes da cidade um pouco da vida cotidiana em um território desconhecido. $\mathrm{O}$ texto aponta a consolidação de um imaginário que associava sambistas, malandros e pureza cultural, e este repertório de imagens muito em breve viria a ser associado à própria nação.

Tal repertório de imagens não era contudo específico de alguns jornalistas dispostos a celebrar a vida nos morros. Chega a ser surpreendente notar que mesmo as páginas policiais chegam a utilizá-lo, como se nota em uma matéria sobre um desentendimento entre dois moradores do morro de São Carlos, que terminou em morte por facada ${ }^{12}$. A desavença havia ocorrido em meio a uma roda de samba, e isto serviu de mote para a matéria, que tem um tom romantizado e mostra o morro como um lugar onde há crime, mas também como espaço onde pessoas simples cantam sambas. A matéria, pouco usual em se tratando de uma página policial, abre-se com

Dia pardacento, morno. Feriado. Lá em baixo, na esquina do Estácio quem tinha de subir o morro de S. Carlos parava a tomar fôlego. Eram 13 horas, e ali estavam juntos para a subida [segue uma lista com nome e profissão dos envolvidos e testemunhas]. O Zuca é sambista máximo do morro. Vinha tranteando um samba. Foi recebido com o costumado agrado.

- Estou ensaiando um samba que é um número.

- Que samba é, Zuca?

- "O Melhor do Mundo".

- Vamos ao ensaio!

A narração mostra ainda os episódios da desavença entre o ajudante de caminhão José Justiniano, o "Paulista", e o "rixento e mau" Walter Januário Gomes, que por ser digno de tais adjetivos, não era aceito na roda de samba, o que originou toda a rixa, que terminou com a morte do primeiro. Mas esta narração é entrecortada com trechos idílicos como o ensaio do samba e a descrição do que Paulista, enquanto tomava sua cachaça na vendinha da vizinhança, pensava nos últimos momentos antes do desenlace: "Paulista havia passado toda a tarde a cantar. Aquele samba como que o havia tornado, pela sua toada, nostálgica, um tanto melancólico". 
Esse texto é, assim, bastante significativo, pois tematizava um evento para o qual já havia um repertório de imagens bastante antigo que poderia ser utilizado. Não seria surpresa se a morte de Paulista fosse narrada cruamente, em meio a observações sobre a "costumeira violência" do morro de São Carlos, no entanto, o repórter responsável pela cobertura do crime preferiu lançar mão de um outro repertório, centrando sua narrativa em uma idílica roda de samba em que todos os participantes têm nome e profissão definida, ao passo que o assassino é mostrado como um outsider a este ambiente, não fazendo parte da roda de samba por ser "rixento e mau". Aqui, tanto o morro quanto a roda de samba e seus participantes são colocados fora do mundo do crime, mostrando que esse repertório de imagens parecia estar amplamente difundido, chegando às seções policiais, que não são propriamente caracterizadas por servirem de espaços para experimentos ideológicos. Assim, vê-se que, ao final dos anos 1920, já é possível notar que samba e malandragem passaram a ser vistos como representantes típicos da "alma popular", associação esta que criava uma poderosa rede simbólica, associada à nação, que era definida assim em termos de pureza, autenticidade, vigor, mestiçagem e auto-suficiência.

Mas, se por um lado a associação entre morro, samba e malandragem consolidava uma imagem que se buscava de nação e contribuía para os novos compositores e o ritmo que utilizavam, do outro lado a velha guarda protestava, sentindo-se excluída nos novos tempos. Sinhô foi evidentemente um compositor que soube perceber as dificuldades que atravessaria com esta nova maneira de se pensar o termo "samba". Convidado por um repórter do Diário Carioca a depor sobre a evolução do samba, o "Rei do Samba" queixava-se:

A evolução do samba? Com franqueza, não sei se o que ora se observa devemos chamar de evolução. Repare bem nas músicas deste ano. Os seus autores, querendo introduzir-lhes novidades ou embelezá-los fogem por completo do ritmo do samba. O samba, meu caro amigo, tem a sua toada e não se pode fugir dela. Os modernistas, porém, escrevem umas coisas muito parecidas com marcha e dizem que é samba. E lá vem sempre a mesma coisa: "Mulher! Mulher! Vou deixar a malandragem". "A malandragem eu deixei". "Nossa Senhora da Penha". "Nosso Senhor do Bonfim". Enfim, não fogem disso (CABRAL, 1996:36). 
Neste artigo de jornal, não por acaso de janeiro de 1930, além de criticar as modificaçôes melódicas sofridas pelo que considera ser o verdadeiro samba, Sinhô introduz a exaltação da malandragem como elemento central do novo ritmo que lhe desagrada. Parecia perceber que se aproximava, via samba malandro, uma nova fase dentro da música popular brasileira dentro da qual possivelmente seu estilo não teria lugar. À geração de compositores ligados ao maxixe, e que buscava um lugar ao sol em espaços como lojas de partituras, sociedades carnavalescas e no teatro de revista, se sucedia um novo grupo, que viam no rádio e no disco os lugares privilegiados de difusão cultural. Era uma nova fase da massificação cultural.

$\mathrm{Na}$ mesma linha, vale notar uma reportagem do jornal $A$ Noite, que opunha a geração de Ismael Silva à de Sinhô. A matéria associava o primeiro ao samba, denominado "a voz do morro", e o segundo ao maxixe, "a voz das ruas". O texto é construído a partir da constatação do sucesso avassalador do samba, que é a razão atribuída pelo jornal ao "desaparecimento do maxixe". O samba é nesta visão inteiramente associado aos morros: "Para dizer a verdade não falta ao morro um bamba, mulato de qualidade, que não cante bem o samba”. Não deixa de ser contemplada a sua imagem de pureza, bem como seu caráter alegórico da nacionalidade:

$\mathrm{Na}$ sua linguagem imaginosa e rude, o "bamba" diz verdades. Tem coragem.

Não sabe mentir, não precisa tapear.

É bem o reflexo das ruas. Por isso não é branco, não é preto; é verde e amarelo.

Para responder à pergunta formulada pelo repórter ("Ainda há quem dance o maxixe?”) é entrevistado o dançarino Lourenço Mariano, ex-parceiro da atriz Hermínia Santos na dupla Os Mignons. Este afirma que

o samba não é verdadeiramente brasileiro (...). É o samba um misticismo que se ambienta perfeitamente à nossa psicologia. É um amálgama de ritmos de procedências diversas. Deram-no ao carioca. Ele gostou e popularizou-o.

Por outro lado afirma ser o maxixe uma dança que agrada a todos em todo o mundo, mas que é puramente nacional: "E eis aí, meu amigo, porque disse ser o maxixe essencialmente brasileiro: só no Brasil é que se sabe dançar maxixe" ${ }^{13}$. Tal como a fala de Sinhô, o depoimento de Mariano mostra que os nomes de maior sucesso da música popular dos anos $1910 \mathrm{e}$ 
20 percebiam que esta voga do samba malandro era um perigo às posições estabelecidas naquele campo. Percebendo que o grande apelo de sambistas e malandros era o fato de serem vistos como tipicamente nacionais, Mariano atacou este aspecto do samba, enquanto Sinhô alfinetava o que via como sendo a falta de criatividade dos novos autores, o que não deixava de ser um ataque a um ponto ressaltado em artigos que exaltavam a figura do malandro, vendo nos compositores de morro um manancial infinito de novas criações.

Com isto, é possível perceber que além da existência de questões técnicas e artísticas, o momento histórico foi parte decisiva na incorporação do samba e da malandragem como símbolos nacionais. O samba malandro surge em um momento em que se buscava nas classes populares os parâmetros para uma nova maneira de se pensar a nacionalidade. Embora o maxixe também possuísse elementos para ser caracterizado como produto tipicamente nacional oriundo das classes populares, o samba e a malandragem em conjunto se mostraram mais adequados ao momento histórico, acabando por serem aglutinados em um repertório de imagens que simbolizava ingenuidade, juventude e pureza nacional. Neste caso, a associação entre ambos se tornou poderosa a ponto de transformá-los em duas instituições mitificadas como alicerces da nação, preservadas com orgulho como parte central da identidade nacional.

\section{Bibliografia}

ALENCAR, Edigar de. Nosso Sinhô do Samba. Rio de Janeiro: Funarte, 2a edição, 1981.

. O Carnaval Carioca Através da Música. Rio de Janeiro: Francisco Alves, 1985.

AUGRAS, Monique. A Ordem na Desordem. Revista Brasileira de Ciências Sociais, no 21, 1993.

AZEVEDO, Célia M. M. Onda Negra, Medo Branco. Rio de Janeiro: Paz e Terra, 1987.

BARBOSA, Orestes. Samba. Rio de Janeiro: Funarte, 2a edição, 1987.

CABRAL, Sérgio. 1996. As Escolas de Samba do Rio de Janeiro. Rio de Janeiro: Lumiar.

CALDAS, Waldenyr. Iniciação à Música Popular Brasileira. São Paulo: Ática, 1985. 
CÂNDIDO, Antônio. Dialética da Malandragem. Revista do Instituto de Estudos Brasileiros, nº 8, 1970.

CASTELLO, José. Vinícius de Moraes. São Paulo: Companhia das Letras, 1997. CHARTIER, Roger. Texto, Símbolos e o Espírito Francês. História: questôes e debates, no 24, 1996.

CHAUÍ, Marilena. Apontamentos para uma Crítica da Ação Integralista Brasileira. In: CHAUÍ, Marilena e FRANCO, Maria Sylvia Carvalho. Ideologia e Mobilização Popular. Rio de Janeiro: Paz e Terra, 2a edição, 1985.

CUNHA, Maria Clementina P. Ecos da Folia. São Paulo: Companhia das Letras, 2001. DA MATTA, Roberto. Carnavais, Malandros e Heróis. Rio de Janeiro: Guanabara, $5^{\text {a }}$ edição, $s /$ d.

DARNTON, Robert. O Grande Massacre de Gatos. Rio de Janeiro: Graal, 2a edição, 1996.

EFEGÊ, Jota. Maxixe: a dança excomungada. Rio de Janeiro: Conquista, 1974.

GOMES, Tiago de Melo. Lenço no Pescoço: o malandro no teatro de revista e na música popular. Dissertação de Mestrado, IFCH-Unicamp, 1998.

KRAUSCHE, Valter. Música Popular Brasileira. São Paulo: Brasiliense, 1983.

LAGO, Mário. Na Rolança do Tempo. Rio de Janeiro: Civilização Brasileira, 1976.

MATOS, Cláudia. Acertei no Milhar. Rio de Janeiro: Paz e Terra, 1982.

MÁXIMO, João e DIDIER, Carlos. Noel Rosa. Brasília: Linha Gráfica-UnB, 1990.

OLIVEN, Ruben George. A Malandragem na Música Popular Brasileira. Latin American Music Review, 5:1, 1984.

PAIVA, Salvyano Cavalcanti. Viva o Rebolado! Rio de Janeiro: Nova Fronteira, 1991. PEDRO, Antônio. Samba da Legitimidade. Dissertação de Mestrado, FFLCHUSP, 1980.

RUIZ, Roberto. Araci Cortes: linda flor. Rio de Janeiro: Funarte, 1984.

SEVCENKO, Nicolau. Orfeu Extático na Metrópole. São Paulo: Companhia das Letras, 1992.

TINHORÃO, José R. Pequena História da Música Popular. Rio de Janeiro: Art, 1991. VASCONCELLOS, Gilberto. Yes, nós temos malandro. In: Música Popular: de olho na fresta. Rio de Janeiro: Graal, 1977. 
VASCONCELLOS, Gilberto e SUZUKI JR., Matinas. A Malandragem e a Formação da Música Popular Brasileira. In: FAUSTO, Bóris (Dir.). História Geral da Civilização Brasileira. São Paulo: Difel, 1984, vol. 11.

VENEZIANO, Neyde. O Teatro de Revista no Brasil. Campinas: Ed. Unicamp, 1991. . Não Adianta Chorar. Campinas: Ed. Unicamp, 1996.

VIANNA, Hermano. O Mistério do Samba. Rio de Janeiro: Zahar-Ed. UFRJ, 1995.

\section{Notas}

${ }^{1}$ Note-se que neste artigo se discute a malandragem enquanto temática associada à música popular dos anos 1920 e 1930, e não a malandragem e seu papel na identidade nacional em um plano mais geral, razão pela qual textos fundamentais como os de Antônio Cândido (1970) e Roberto da Matta (s. d.) não serão foco da análise aqui empreendida.

${ }^{2}$ Com ligeiras variações, diversos autores desenvolveram tal idéia, ver MATOS (1982), OLIVEN (1984), VASCONCELLOS (1977), VASCONCELLOS e SUZUKI JR. (1984) e PEDRO (1980).

${ }^{3}$ Aqui se pode lembrar a análise feita por Darnton (1996) dos contos populares franceses, nos quais freqüentemente aparecem trapaças muito similares àquelas vistas por aqui como “tipicamente brasileiras". Na verdade é curioso notar que Darnton, partindo de tais contos, tenha concluído que existiria um "espírito francês" que teria essa espécie de "malandragem" como parte importante, o que abriu espaço para contundente crítica de Chartier (1996).

${ }^{4}$ Um número infindável de autores tem repetido que tal canção originalmente conteria a palavra "otário" no lugar de "operário" (“O bonde São Januário/leva mais um operário/ sou eu que vou trabalhar"), afirmando que a mudança teria sido exigência da censura. Contudo, nenhum destes autores refere-se a qualquer tipo de fonte, para não mencionar o fato de que a palavra "otário" simplesmente é impossível de ser cantada no lugar de "operário” na música, de modo que fica difícil não suspeitar que esta seja mais uma das lendas da música popular brasileira, perpetuada indefinidamente por trabalhos desejosos de mostrar a censura getulista em ação.

${ }^{5}$ Sobre a constituição destes tipos VENEZIANO, 1991, Cap. 4.2.

${ }^{6}$ Música cantada na citada revista Vamos Deixar de Intimidade. Sua autoria é discutida, fato comum entre composições apresentadas em peças de teatro musicado: RUIZ (1984:134), conjectura que a autoria seria de Ari Barroso e Olegário Mariano. Já PAIVA (1991:320) afirma que o autor teria sido o maestro Sá Pereira, ambos sem apresentar fontes.

${ }^{7}$ Naturalmente o rótulo "música sertaneja” na verdade comporta uma razoável diversidade de gêneros que nem sempre se confundem. Aqui serão utilizados termos genéricos devido ao fato de que esses tipos de música pareciam ser consumidos desta maneira pelo público urbano. 
${ }^{8}$ Havia músicas auto-intituladas "samba" nos anos 1910 e 20, mas em um sentido diverso do conhecido hoje. O conceito de samba empregado atualmente está mais próximo de um ritmo de fins dos anos 1920, criado no bairro do Estácio, por compositores como Ismael Silva e popularizado por outros, como Noel Rosa e Ari Barroso. Já o “samba” dos anos 1920 é tido hoje como "maxixe". Aqui o ritmo de Ismael e Noel será denominado "samba", enquanto que a música produzida por Donga e Sinhô estará designada como "maxixe”. Isto na verdade não se refere a uma tomada de posição a respeito, mas apenas uma convenção para que não haja confusão entre diversas acepções do termo "samba" neste artigo.

9 "Mulheres Decididas no Perigoso Morro de Mangueira", O Imparcial, 1-10-26.

10 “O Morro do Pinto Modernizado", A Noite, 14-2-28.

11 "O Morro do Pinto Modernizado", A Noite, 17-2-28.

12 "Ensaiando o Samba", $A$ Noite, 23-1-32.

13 "Samba ou Maxixe?", A Noite, 18-1-33.

\section{Resumo}

Este artigo estuda o samba malandro no final da Primeira República, tendo por objetivo mostrar um dos caminhos através dos quais se construiu uma identidade nacional brasileira fundada em conceitos como "mestiçagem", "pureza" e "cultura popular".

Palavras-chave: samba, malandragem, Primeira República, Identidade Nacional.

\section{Abstract}

This article studies the samba malandro in the end of First Republic. The goal is to show an important way of construction of a national identity based on ideas as mestiçagem, "pureness" and "popular culture". Key Words: samba, malandragem, First Republic, Brazilian National Identity. 